\title{
Effect of novolac nanoparticles additions on specific gravity of NBR/CR blends
}

\author{
Mohammed H. Al-Maamori ${ }^{1}$, Ali I. Al-Mosawi ${ }^{2,}{ }^{*}$ and Shaymaa Abbas Abdulsada ${ }^{2}$ \\ ${ }^{1}$ College of Engineering Materials, Babylon University, Babylon, Hilla, IRAQ \\ ${ }^{2}$ Faculty of Materials Science and Engineering, University of Miskolc, Hungary
}

\begin{abstract}
In this article, novolac nanoparticles with different weight fraction (0-40) wt.\% were added to NBR/CR blends and investigate the effect of these additions on the specific gravity of rubber blend. The results obtained shown that the novolac nanoparticles works on increasing the specific gravity of NBR/CR blends, and specific gravity ratio increases with increased novolac nanoparticles percentage.
\end{abstract}

\section{Introduction}

Elastomer is currently used in a wide range of applications, such as cables, wires and cars, because of its light weight, ease of maintenance and processing, high durability, low cost manufacture. However it was usually applied in the case since the reinforced rubber reinforcement carbon black discovered a century ago as in the tire industry, conveyor belts and other applications, including carbon black, silica reinforcement fillings, resins, calcium oxide, calcium carbonate and other stimulant that increases the power of Vulcanized more than ten times [1-3]. Besides the fortification patterns another way to strong rubber and change its properties, namely blending. The objective of blending process of two or more rubber types is to (1) enhancement in mechanical properties, (2) better processing characteristics, and (3) reducing compound cost. Blending of rubbers can be practically carried out in several different ways, which consists of latex; solution blending; and mixing of solid rubbers-on mills, in internal mixers or during continuous mixing, sometimes in particulate or powder form. The performance of rubber blends depends on the ability of their components to miscible with each other, where the blends that have good miscibility and phase adhesion between are better performing than those that are weakly blending [411]. Polybutadiene rubber (BR), polystyrene-butadiene rubber (SBR), natural rubber (NR), nitrile rubber (NBR), and their blends are all important materials in the rubber industry. The morphologies of these blends control the glass transition behavior and their properties. Therefore, morphology and miscibility represent important design factors in rubber compounding [12]. Many studies have dealt with the process of blending the different types of rubber, and the impact on the properties of rubber. Hanafi, S.Tan, and B.T.Poh, studied the curing and mechanical properties of nitrile (NBR/NR) blends. Results indicate that the scorch and cure time torque, torque difference, $\mathrm{MH}$ and viscous torque will increase with increasing NBR content in both blends [13]. Mohammad was studied the mechanical and

*Corresponding author: aliibrahim76@yahoo.com 
rheological properties of engine mounting manufactured from NBR reinforced by novolac and rise husk powder [14]. Madbouly and Otaigbe published a review article some new insights into the synthesis, characterization, structure evolution and kinetics, and rheological properties for a number of blends [15]. Khalaf, Yehia, Ismail, and El-Sabbagh were studied the characteristics of blends (NBR/PVC, PVC/CR, NBR/PVC/CR) by rheological properties, mechanical analysis and swelling in oil and toluene [16]. Mohammad, Ali and Fasal studied the change in rheological properties of natural rubber after adding shells powder with various amounts (50,100,150 pphr) [1]. Mohammad and Ali were studied the effect of different weight fraction $(15,25,35 \mathrm{pphr})$ from calcium carbonate scorch time, viscosity and max torque of natural rubber [17]. Mohammad, and Ali studied the mechanical and rheological properties of rubber rollers reinforced by cement and rise husk waste [18].

Mohammad, Ali, and Haider were studied the mechanical behavior of AcrylonitrileButadiene Rubber (NBR) after added PVC with different volume fraction [19]. Mohammad, Ali and Laith were used shells powder as filler in their research which adding to natural rubber with different amount and studied its effect on mechanical properties of rubber which includes hardness and tensile strength [20]. Jayasree and Predeep published an article about the effect of silica, HAF-carbon black, china clay and titanium oxide as fillers on the mechanical properties of SBR-HDPE system blends [21]. Ramesan was studied in his paper the effect of carbon black on mechanical properties and curing of dichlorocarbene modified styrene butadiene rubber (DCSBR) [22]. Suzuki, Ito and Ono where investigated in their article about the effects of interactions between nitrile butadiene rubber (NBR) and silica fillers on the evaluations of agglomerates by precipitated silica particles and bound rubber in NBR/silica blends which were prepared by solution mixing and mechanical mixing [23]. Ali, Shaymaa, Kálmán, and Mohammed published a paper about adhesion force between NBR/CR blend and copper coated steel wire and non-coated wire in tires industry as a function to novolac nanoparticles additives [24]. Mohammed, Ali, and Shaymaa were studied the effect of novolac nano additives (0- 40) wt.\% on hardness, resilience, and Compressibility of NBR/CR hybrid blends [25].

\section{Methodology}

\subsection{Materials}

Acrylonitrile Butadiene Rubber (NBR) and Chloroprene Rubber (CR) as a rubber blend, Novolac nanoparticles $(1 \mathrm{~nm})$, with addition of some of materials (such as zinc oxide, stearic acid, sulfur, Antioxidant, Carbon black, etc. which shown in Table 1.

Table 1. Composition of batch.

\begin{tabular}{|c|c|c|c|c|c|c|c|c|}
\hline $\begin{array}{c}\text { Compounding } \\
\text { Ingredients }\end{array}$ & $\begin{array}{c}\mathrm{NBR} \\
\text { /CR }\end{array}$ & $\mathrm{ZnO}$ & $\begin{array}{c}\text { Stearic } \\
\text { acid }\end{array}$ & DOP & TMTD & Antioxidant & $\mathrm{S}$ & $\begin{array}{c}\text { Novolac } \\
\text { nanoparticles }\end{array}$ \\
\hline Ratio, pphr & $50 / 50$ & 3 & 1 & 1 & 1.5 & 1.5 & 1.5 & $0-40$ \\
\hline
\end{tabular}

\subsection{Specific gravity samples:}

These samples were prepared according to ASTM D1817 standard as a disk shape. The mold was used to fabricate samples shown in Figure 1. 

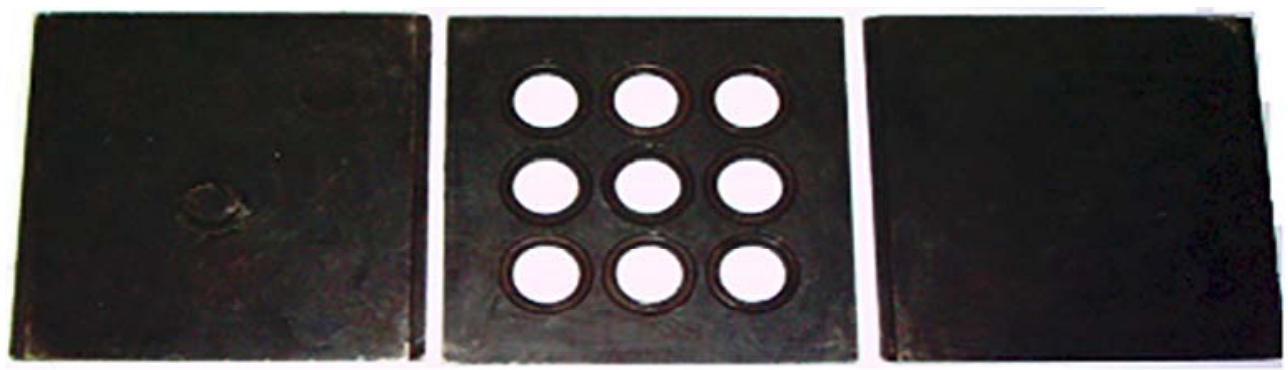

Fig. 1. Mold of specific gravity samples [14].

\subsection{Measuring of specific gravity:}

Monsanto-Densitron 2000 equipment was used to measuring specific gravity and it is shown in Figure 2.

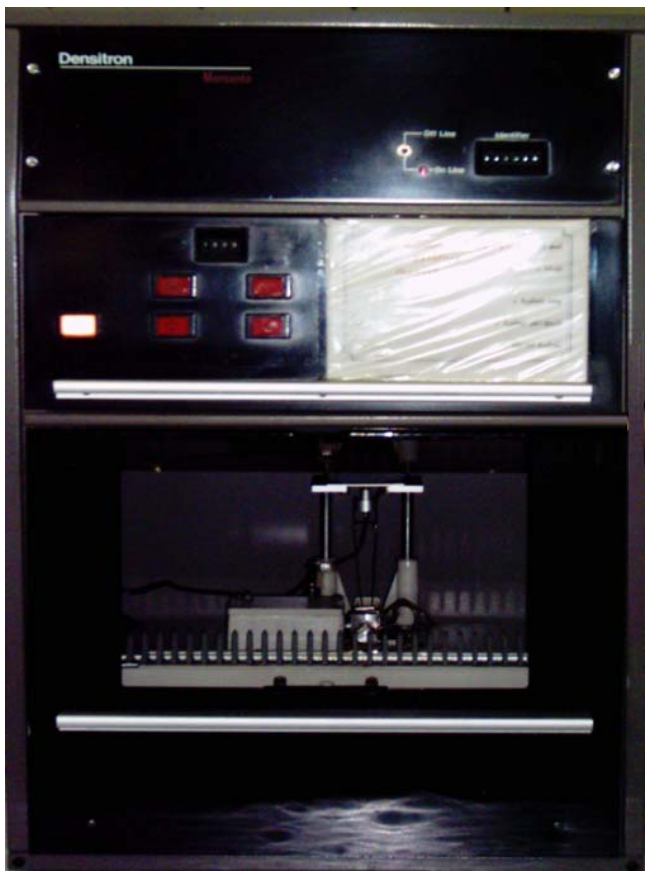

Fig. 2. Monsanto-Densitron 2000 equipment.

\section{Results and discussion}

Figure 3 shows the interaction between the specific gravity of NBR/CR blends and various weight percentages of the novolac nanoparticles. From this figure we can be observed that the specific gravity increases as the novolac nanoparticles percent increases. This behavior is due to the decreases in voids between the rubber chains where the novolac nanoparticles will acts as a plasticizer inside blend structure. As the temperature increases, novolac nanoparticles make crosslinking with the methenamine resulting in compact blend. All this will raise and improved specific gravity of rubber blends. The specific gravity of rubber blends will continue to rise with the increase in the novolac nanoparticles percentage. These results agree with other works [6]. 


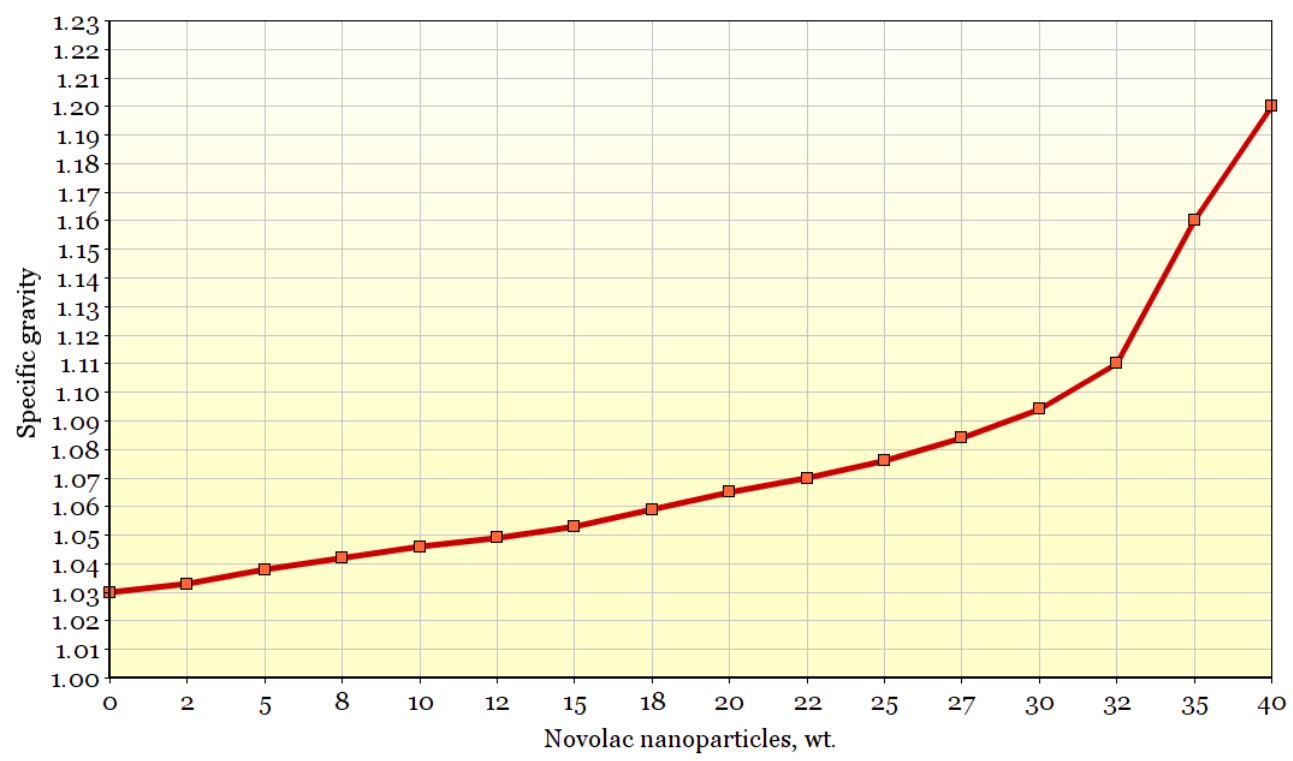

Fig. 3. Specific gravity of NBR/CR vs. novolac nanoparticles wt.\%.

\section{Conclusions}

Improved specific gravity of NBR/CR blends with the addition of novolac nanoparticles, because it is working on filling the blanks interfaces chains voids, which raising the value of the specific gravity. And this rise in specific gravity continues with increasing proportion of novolac nanoparticles added.

\section{References}

1. M. H. Al-Maamori, A.I. Al-Mosawi, and A. Fasal, Iraqi Journal of Polymers, 16, 1, pp. 71-74 (2012)

2. A.I. Al-Mosawi, M.M. Ali, and J.H. Mohmmed, International Journal of Physical Sciences, 7, 49, pp. 6280-6282 (2012)

3. A.I. Al-Mosawi, Journal of Materials Physics and Chemistry, 1, 3, pp. 35-36, (2013).

4. D.J. Walsh, J.S. Higgins, A. Maconnachie (editors), Martinus Nijhoff Publishers, Dordrecht, The Netherlands, Published in cooperation with NATO Scientific Affairs Division (1985)

5. S. Desai, I. M. Thakore, A. Brennan, and S. Devi, Journal of Macromolecular Science, Part A: Pure and Applied Chemistry, 38 , 7, pp. $711-729$ (2001)

6. A.I. Al-Mosawi, Create space Independent Publishing Platform, $1^{\text {st }}$ edition (2015)

7. S.H. Botros and M.L. Tawfic, Polymer-Plastics Technology and Engineering, 44, 2, pp.209-227 (2005)

8. M.H. Al-Maamori, A.I. Al-Mosawi, Al-Sadiq for Publishing and Distribution (2014)

9. K. Ahmed, Journal of Advanced Research, 6, 6, pp. 811-817 (2015)

10. A. Shundo, A. Ijioto, and Y. Minoura, Journal of applied polymer science, 10, pp. 939-953 (1966)

11. A.I. Al-Mosawi, LAP LAMBERT Academic Publishing, $1^{\text {st }}$ edition (2012)

12. D.J. Hourston and M. Song, Journal of Applied Polymer Science, 76, pp.1791-1798 (2000) 
13. H.Ismail, S. Tan, B. T. Poh, Journal of Elastomers and Plastics, 33, 4, pp. 251-262 (2001)

14. M.H. Al-Maamori, PhD thesis, UOT, IRAQ, (2006)

15. S.A. Madbouly, J.U. Otaigbe, Progress in polymer science, 34, 12, pp. 1283-1332 (2009)

16. A. I. Khalaf, A. A. Yehia, M. N. Ismail, S. H. El-Sabbagh, Open journal of organic polymer materials, 2, pp. 88-93 (2012)

17. M.H. Al-Maamori, A.I. Al-Mosawi, Proceeding of $3^{\text {rd }}$ scientific international conference, Technical college-Najaf, IRAQ, pp. 706-712 (2013)

18. M.H. Al-Maamori, A.I. Al-Mosawi, Central Organization for Standardization and Quality Control (COSQC), International Classification (C08C19/42), No.3913, Iraqi Classification (4), (2014)

19. M.H. Al-Maamori, A.I. Al-Mosawi, and H.A. Yasser, Proceedings of $1^{\text {st }}$ national conference for engineering, Engineering College, University of Mustansiriyah, Iraq, pp. 231-235 (2014)

20. M.H. Al-Maamori, A.I. Al-Mosawi, and L.M. Saadon, International Journal of Technical Research and Applications, 1, 3, pp. 31-33 (2013)

21. T.K. Jayasree and P. Predeep, Journal of elastomers and plastics, 40, pp. 127-146 (2008)

22. M.T. Ramesan, Journal of polymer research, 11, 4, pp. 333-340 (2005)

23. N. Suzuki, M. Ito, and S. Ono, Journal of applied polymer science, 95, 1, pp. 74-81 (2004)

24. AI. Al-Mosawi, S.A. Abdulsada, K. Marossy, and M.H. Al-Maamori, Multi Science XXXI. micro CAD International Multidisciplinary Scientific Conference, University of Miskolc, Hungary, (2017)

25. M.H. Al-Maamori, A.I. Al-Mosawi, and S.A. Abdulsada, Journal of Thin Films, Coating Science Technology and Application, 4, 1, pp.13-17 (2017) 